\title{
Adding Value (with Limits): Pilgrimage and Women's Exclusion in Japan's Sacred Mountains
}

CALEB CARTER

Kyushu University, Faculty of Humanities

ccarter@lit.kyushu-u.ac.jp

Keywords: Buddhist mountain pilgrimage, temple economics, women's exclusion, nyonin kekkai, nyonin kinsei, Mount Togakushi, Mount Fuji

DOI: https://dx.doi.org/10.15239/hijbs.02.02.01

Abstract: This article examines competing interests over pilgrimage and women's exclusion at numinous mountains in early modern Japan. Developing new forms of ritual and practice, Buddhist clerics encouraged pilgrimage to mountain temples as a source of revenue. Many of these temples, however, simultaneously increased the exclusion of women from certain areas of their premises. What explains this seeming contradiction? Through the case of Mount Togakushi (Nagano prefecture), this article explores the historical coincidence of pilgrimage growth with discriminatory policies targeting women in early modern Japan. It builds from research in the fields of pilgrimage and women's studies, offering insight into how pilgrimage and women's exclusion often intersected among competing interests within regional mountain communities. 
Tmagine for a moment that you were alive in eighteenth-century located in the northern peaks of Shinano 信濃 province (present-day Nagano prefecture). After a long day's hike uphill from the temple of Zenkōji 善光寺 in the plains below, you enter the Togakushi region (Figure 1). A short break at the Ōkubo 大久保 Teahouse provides a moment of respite. Resting outside of its thatch-roofed hut with a cup of tea, you gaze at an array of passersby: clerics of the mountain's fifty-three cloisters, local rice and soba farmers, loggers, charcoal producers, and basket weavers. Beyond local residents, you see scores of travelers, especially if the timing coincides with a festival or the mountain-climbing season. Members of regional confraternities stream past, led by temple clerics and village yamabushi 山伏 (religious mountain specialists). Lone travelers walk by too, some coming from as far as Edo (about eight days on foot). ${ }^{1}$

Resuming your journey, you turn left at a fork and ascend a road lined with temple cloisters (in 院), operated by the clerics and available for accommodations. These lead to Hōkōin 寶光院, the first of the three main temples of Togakushi. From Hōkōin, you continue a short distance before arriving at another stretch of cloisters that lead to the temple of Chūin 中院.

A short walk beyond, you come to another fork, yet significantly, the path for you from this point forward will be determined by your gender. If you are male, you can proceed ahead unimpeded, turning left before entering a woodsy, cedar-lined path that eventually ascends to the mountain's most numinous places: Okunoin 奥院, or the 'innermost temple'; a neighboring hall for Kuzuryū daigongen 九頭龍大權現, enshrinement site of the mountain's most celebrated deity, a nine-headed dragon; and a trail up into twin peaks behind Togakushi that represent a divine topography of dual mandalas. If you have imagined yourself as female, however, your journey ends here, made obvious by a stone pillar announcing the prohibition of

1 Kobayashi, Zenkojii shi kenkyū, 366. Kobayashi estimates the journey from Edo to Zenkōji as roughly six nights, which I convert to about seven days plus an extra day to reach Togakushi. 




FIG. 1 Visitor's map for Mount Togakushi from the late Edo period. The shaded area (added by the author) shows the approximate zone of exclusion for women. The area encompassed Okunoin and its cloisters, the shrine for the mountain's central deity Kuzuryū, the mountain of Togakushi (left, fore), and the two-realm mountains (centered, rear). The women's hall (circled) marked the final destination accessible to women. Shinshū Togakushisan sōryaku ezu, $38 \mathrm{~cm} \mathrm{x}$ $56 \mathrm{~cm}$. Author's collection, photo taken by Lachlan Hill.

women beyond this point. Nearby is a small 'women's hall' (nyonin $d \bar{o}$ 女人堂) where you may pray before turning back. This restriction will remain in effect at Togakushi for decades, probably long past your lifetime. ${ }^{2}$

2 The exclusionary zone at Togakushi remained formal policy until 1870, two years before the Meiji government issued an edict calling for an end to the policy nationwide (Ushiyama, 'Historical Development of the Exclusion', 44). The practice continued at some sites well into the Meiji period (and even down to the present in a few cases), as examined by Lindsey DeWitt ('A Mountain Set Apart'; 'Envisioning and Observing Women's Exclusion'). 
The imagined scenario above recalls a complex set of practices at Mount Togakushi and many other numinous mountains in eighteenth-century Japan. What is surprising is that temples like those at Togakushi were encouraging more visitors while simultaneously restricting nearly half of the population from their most numinous and sought-after areas. ${ }^{3}$ This paradox, as it would seem, sets up two intersecting paths of investigation in the following article: first, the development of pilgrimage to numinous mountains in early modern Japan, often with economic interests in mind; and second, the heightened enforcement of gendered rules of exclusion, which may have impeded those very gains.

Scholars of East Asian Buddhism have long been aware of the important role of pilgrimage and travel within ritual and practice. ${ }^{4}$ This activity grew especially in Edo period Japan (ca.1600-1868), though scholars in the latter half of the twentieth century problematically associated the economic side of this activity with spiritual decline. Historians in various fields, beginning with Tsuji Zennosuke (in Japanese Buddhism), Shinjō Tsunezō (in pilgrimage studies), and Wakamori Tarō (in Shugendō 修験道), often took the financial interests of early modern clerics and laity as signs of moral decay from what they deemed to be a spiritual golden age in the medieval period. ${ }^{5}$ Gregory Schopen and others have contended that this type of judgment has

3 The relatively common practice of infanticide in early modern Japan typically targeted girls at higher rates than boys, contributing to less women than men (Drixler, Mabiki, 32-33).

4 Examples for Chinese pilgrimage include Naquin and Yü, Pilgrims and Sacred Sites in China; Yü, Kuan-yin; and Robson, Power of Place. In her forthcoming book (which she kindly shared), Maya Stiller argues that 'status pilgrimage' (her term) became an important social practice among elites during the Chosŏn dynasty. Conversely, Buddhist pilgrimage on the Korean peninsula was historically less significant as a phenomenon.

5 Tsuji, Nihon bukkyō shi; Shinjō, Shinkō shaji sankei; and Wakamori, Wakamori Tarō chosakushū, vol. 2, especially 210-37. 
its roots in Protestant values. ${ }^{6}$ Anthropologist Ellen Badone similarly notes that pilgrimage studies more broadly have been influenced by a series of Protestant-based binaries: scripture versus ritual, asceticism versus materialism, pilgrimage versus tourism, and so forth. ${ }^{7}$ In eighteenth-century Japan, however, these binaries were largely opaque. In recent decades, a growing body of scholarship has explored the topic of pilgrimage and sightseeing in early modern Japan in less value-laden terms, offering a more nuanced picture. ${ }^{8}$ Religious historians such as Tamamuro Fumio, Nam-lin Hur, Sarah Thal, and Barbara Ambros have done so by examining religious, social, and political developments through close investigations of specific sites. ${ }^{9}$ Laura Nenzi's work, furthermore, has centered on issues concerning the participation of women in early modern travel and pilgrimage. ${ }^{10}$

Building on these works, this article explores how economic incentives propelled new rituals, beliefs, and practices. These activities at Togakushi included the expansion of regional confraternities ( $k \bar{o}$ 講), promotion of the mountain's central deity (a nine-headed dragon), absorption of new forms of Shintō, the introduction of lay mountain climbing, and increased coordination with the mountain-based tradition of Shugendō. ${ }^{11}$ These developments invited a broad range of interests among a populace that was increasingly mobile, traveling long distances to visit famous sacred sites, and ready to spend money on the effort. Buddhist clerics residing at

6 Schopen, 'Archeology and Protestant Presuppositions'.

7 Badone, 'Crossing Boundaries'.

8 General studies in the field include Shinno, 'Journeys, Pilgrimages, Excursions'; Reader, Making Pilgrimages; and Pye, Japanese Buddhist Pilgrimage.

9 Tamamuro, Nibon bukkyō shi; Hur, Prayer and Play; Thal, Rearranging the Landscape; and Ambros, Emplacing a Pilgrimage, and 'Geography, Environment, Pilgrimage'.

10 Nenzi, Excursions in Identity, and The Chaos and Cosmos of Kurosawa Tokiko.

11 While a comprehensive look at these trends exceeds the scope of the present article, my current book project examines them, with a focus on the historical formation of Shugendō. 
well-known mountain temples were keenly aware of the economic potential that lay in these trends and strove to capitalize on it.

Yet there was a caveat, and this leads to the second issue. Access to certain places and practices was only extended to men, while exclusionary policies against women were intensified. This stark contrast in policy-based on gender-beckons the question: if the religious community at Togakushi was interested in alluring more visitors to their site, why would they dramatically limit women? Indicative of broader trends in the history of Japanese temples, women had faced varying levels of exclusion from the Togakushi as far back as the fifteenth century, but the practice faced controversy and the extent of its enforcement remains unclear (discussed later). At the start of the eighteenth century, however, just as pilgrimage was being actively developed at the site, excluding women became a renewed priority.

The following pages explore this juxtaposition of seeming contradictions-economic expansion and visitorship, on the one hand, and the exclusion of women, on the other-through the case of Togakushi in the eighteenth century, with complementary evidence from Mount Fuji. I focus especially on the commencement of mountain climbing for laymen at the start of the eighteenth century. This policy of increased access not only contrasts with the contemporaneous exclusion of women; alongside increased pilgrimage overall, it seems to have prompted renewed efforts to keep women away from the inner sanctums of the site.

\section{State Support and Oversight}

To understand the economic and institutional structure of Mount Togakushi in the early modern period, it is helpful to briefly recount events in the half century prior. From 1553 to 1564 , the site became a central battleground between the forces of the two famous rival warlords, Uesugi Kenshin 上杉謙信 (1530-1578) and Takeda Shingen 武 田信玄 (1521-1573). Left in ruins, it was not until 1594 that Uesugi Kagekatsu 上杉景勝 (1556-1623), adopted son of Kenshin, would allocate funds for the rebuilding of the temples. Additional support came in the early seventeenth century under the new Tokugawa mil- 
itary government, specifically from its founder Tokugawa Ieyasu 徳 川家康 (1543-1616) and Ieyasu's sixth son Matsudaira Tadateru 松 平忠輝 (1592-1683). Through their patronage, the temples were bestowed one thousand units (koku 石) of arable land as well as the shogun's vermillion seal, which placed the site beyond the jurisdiction of the provincial constable (shugo 守護). ${ }^{12}$ In return, the temples became faithful stewards of the military government, using its capacity as a spiritually potent site to conduct prayers for the well-being of the state and hold regular memorial services for Ieyasu and subsequent deceased shoguns. ${ }^{13}$

The site of Togakushi centered on three main temples: Okunoin 奥院, located directly beneath the mountain, the 'central temple' of Chūin 中院, and slightly further out, Hōkōin 寶光院 (Figure 2). Each temple was managed by Tendai (Ch. Tiantai 天台) clerics residing in the surrounding cloisters (in 院): twelve cloisters were assigned to Okunoin, twenty-four to Chūin, and seventeen to Hōkōin. In addition, there were two shrines: one beside Okunoin for the site's main deity, a nine-headed dragon (Kuzuryū 九頭龍), and Hinomiko shrine 火御子社 (located near the entrance to the site). The entire complex was administered by a Tendai chief administrator (bettō 別當), located directly across from Chūin. In addition to the Tendai clerics, Togakushi was home to a community of yamabushi, or Shugendō mountain specialists residing with their families in the surrounding villages. They worked in concert with the clerics in the management of the cloisters and interaction with the mountain's lay communities. These relations, and their status as yamabushi, were formalized in 1707 in the establishment of Togakushi's own branch of Shugendō. ${ }^{14}$

12 In the Edo period one koku was a unit of measurement representing the land necessary to yield one year's supply of rice for one man. Rice, in turn, was the main form of currency.

13 Furukawa, 'Togakushisan shinryō'.

14 The regulations are listed in the Togakushi-ha yamabushi ninkan no sadame 戸隠派山伏任官之定 [Establishment of the Togakushi-branch yamabushi], discussed and partially transcribed by Wakamori ('Togakushi no Shugendō', 396, 423-26) but has since gone missing from Togakushi Shrine's archives. 


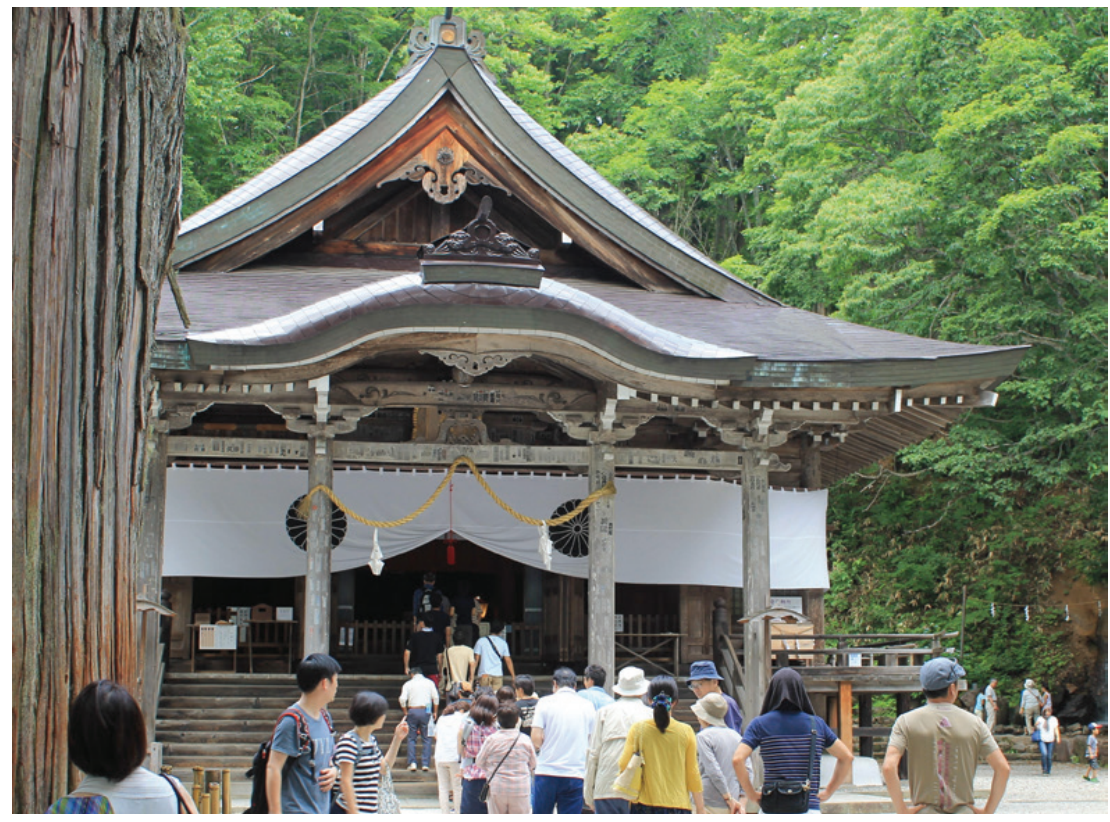

FIG. 2 Chūsha 中社 (Chūin before the Meiji period) as it stands today. The main ritual structures were converted to imperial shrines in the Meiji era (18681912) under the direction of the new government and continue down to the present as Shinto shrines. Photo by Caleb Carter.

With the restoration of Mount Togakushi came heightened influence from the capitol of Edo. Under the shogun's vermillion seal (subject to renewal under each successive shogun), the clerics of Togakushi were obliged to follow regulations aimed at maintaining the current patrilineal community and preventing schisms within it. All disputes, moreover, were settled by the Commissioner of Temples and Shrines (jisha bugyō 寺社奉行), who was appointed by the shogun. In conjunction with this political presence, the site was brought into the Tendai Buddhist institution by Tenkai 天海 (1536?-1643), its chief architect in the seventeenth century. In 1633, Tenkai made Togakushi an immediate branch (jikimatsu 直末) of Kan'eiji 寛永寺, head temple (erected under Tenkai) to the country's Tendai temples. Indicative of broader trends in early modern Japan, this was a sharp break with the past. Before the consolidation of national sectarian organizations, initiated under Tokugawa Ieyasu, tem- 
ples had been oriented more toward particular lineages rather than broad sectarian institutions or identities. The new configuration at Togakushi gave its chief administrator jurisdiction over all Tendai temples in the provinces of Shinano and Echigo 越後 (now Niigata prefecture) while at the same time, making Togakushi more beholden to the institutional authority of Kan'eiji.

Given this support from the government and the Tendai institution, it would seem that the clerics might have simply sat back and limited their efforts to conducting annual rites and prayers on behalf of the state. Two financial factors, however, encouraged them to keep busy. First, the flow of income provided by taxation of the mountain's agricultural estates was unevenly distributed among the temples: half of the allotted land was set aside for the administrator's office, one fifth went to the clerics of Okunoin (for their orchestration of the mountain's most important rituals), and the remainder went to Hinomiko shrine. ${ }^{15}$ This compelled the clerics of Chūin and Hōkōin to seek patronage from regional followers and more distant pilgrims. Second, the land-based income that was available remained relatively fixed, save for the incremental expansion of arable soil over the course of the Edo period. These circumstances gave all members of the temple community, even those affiliated with Okunoin, incentive to develop new rituals, beliefs, and practices that would cultivate an expanded base of patronage for the site.

\section{Pilgrimage and Travel to Togakushi}

Increasing the site's devotees began with the development of regional confraternities. Confraternities were lay-based associations centered on certain sites and their respective divinities. They emerged in the early fifteenth century around the three main shrines of Kumano 熊野 (Kii peninsula), ${ }^{16}$ but this activity spread in the Edo period to prominent religious sites around the country

\footnotetext{
15 Furukawa, 'Togakushisan shinryō', 62-63.

16 Miyake, 'Shugendō', 470.
} 
and became one of the main forms of mountain worship for the general populace. ${ }^{17}$

In the case of Togakushi, scholars have provided a detailed picture of early modern confraternities. ${ }^{18}$ The confraternities were spread across districts throughout the provinces of Shinano and Echigo. Designated territories, distributed among the temples, minimized competition and overlap. From his investigation of extant confraternity records, Iwahana Michiaki finds that worship interests among Togakushi's confraternities coincided with proximity toward the site. Local associations, residing within 50 kilometers of Togakushi, commonly prayed for adequate water supply, which descended into the region via the mountain's streams. This interest was based on the need to transport water throughout the area. Regional confraternities, located 50 to 150 kilometers from the site, prayed for rainfall for agricultural production. Distant confraternities, ranging 150 to 350 kilometers from Togakushi, typically worshipped for a wider variety of reasons, but agricultural productivity remained the most important. ${ }^{19}$ This concentration of water-related interests matched the alleged capabilities of the mountain’s dragon, Kuzuryū 九頭龍. Dragons have long been worshipped across Asia for the manipulation of water and Togakushi was no exception. Propitiated in a modest wooden shrine beside the temple of Okunoin, devotees prayed to Kuzuryū for water-related concerns as well as a broad range of other worldly benefits (genze riyaku 現世利益) such as prosperity, healing, and protection of the household.

Overall activity among Togakushi's confraternities rose significantly over the course of the Edo period. While there is limited evidence from the early seventeenth century, the largest membership for a single cloister reached eight thousand households (with the smallest number at one hundred), according to figures from the late

17 Ambros (Emplacing a Pilgrimage) provides thorough treatment of early modern confraternities in the case of Mount Ōyama.

18 See Miyata, 'Togakushi shinkō to Mimachi'; Hōgetsu, 'Edo jidai ni okeru Togakushi oshi'; and Iwahana, 'Togakushi shinkō no chiikiteki tenkai'.

19 Iwahana, 'Togakushi shinkō no chiikiteki tenkai', 39. 
Edo period. ${ }^{20}$ As leaders of confraternities, the Tendai clerics of the mountain hosted parishioners at their respective cloisters, leading them in prayer ceremonies issued to Kuzuryu and other deities of the mountain; in reciprocation, they made seasonal rounds to the homes of their members. Priests from each respective cloister delivered talismans (ofuda 御札) to their parishioners in the winter and spring. In return, they received coins, rice, and other gifts they would transport home or if cumbersome, exchange for cash en route. These proceeds generated significant income for the cloisters: one ryo 両 (measured by one golden coin) for smaller confraternities and up to twenty-five ryo for the largest. ${ }^{21}$ Distant confraternities were also supported by intermediaries (sewanin 世話人) who coordinated with the clerics in arranging travel to the site and accommodations once there. ${ }^{22}$

In addition to regular patronage of Togakushi by confraternal parishioners, independent travelers ventured to the mountain too, especially from the eighteenth century onward. Dozens of extant travelogues (dōchüki 道中記) from the latter Edo period detail multiweek (and often longer) itineraries that travelers charted out across central and northern Honshū. Among the famous places (meisho 名 所) they visited, Togakushi was commonly listed for sites in Shinano. ${ }^{23}$ Popular gazetteers like Zenkojjido meisho zue 善光寺道名所圖會 (1843), moreover, introduced prospective visitors to the main attractions and festivals for the area. The Zenkojido meisho zue was created and published beyond the purview of the Togakushi temples but gave the site considerable promotion through its idyllic illustrations and descriptions.

All of this traffic to Togakushi added substantially to the coffers of the mountain's temples. It is unclear what percentage of overall

\footnotetext{
20 Hōgetsu, 'Edo jidai ni okeru Togakushi oshi', 347.

21 Hōgetsu, 347. At the beginning of the Edo period, one ryō was ostensibly valued at one koku. However, the value of the ryo dropped precipitously over the course of the Edo period, making estimates difficult.

22 Iwahana, 'Togakushi shinkō no chiikiteki tenkai', 39.

23 Iwahana, 'Kinsei no tabi nikki'.
} 
revenue came from confraternities and independent pilgrimage. As a comparison, estimates for the similar site of Mount Haguro 羽黑 山 (Dewa 出羽 province) suggest that by the nineteenth century, revenue from pilgrimage exceeded the tax returns from Haguro's landholdings (fifteen hundred koku). ${ }^{24}$

\section{The Introduction of Mountain Climbing}

To increase visitors to the site, the clerics developed various practices aimed toward laity. One of these was the chance for laymen to climb two of its most mystical peaks, Takatsuma 高妻山 and Ototsuma 乙妻山, for a short window during the summer. The two peaks, rising behind Mount Togakushi to the north, were long viewed as mandalized geographies representing the Diamond and Womb realms (kongōkai 金剛界 and taizōkai 胎蔵界; Skt. vajradhātu and garbhakosadhātu), with textual evidence dating back to mid-fifteenth century. ${ }^{25}$ Furthermore, these so-called two-realm mountains (ryōkaizan 兩界山) had not been historically climbed by anyone other than yamabushi and other ascetic practitioners in the past. This changed drastically in the summer of 1701 when the chief administrator Ken'yū 見雄 (appointed in 1697; d. 1702) issued a set of regulations permitting the entry of laymen. ${ }^{26}$ This expanded access into the numinous mountains was part of a broader trend around the country, as evident from similar actions at Ōyama 大山 (Kantō region) and Myōkō 妙高 (Echigo province) around this time. ${ }^{27}$ At Togakushi and

\footnotetext{
24 Sekimori, 'Paper Fowl and Wooden Fish', 206.

25 Togakushisan Kenkōji ruki, 378.

26 The regulations were issued in a document titled the Ryokaizan sankei okite jojo- [Regulations for pilgrimage into the two-realm maṇdalas].

27 Within the immediate region, the temples of Sekiyamasha 關山社 and Hōzōin 寶藏院 across the border in Echigo established the practice for Mount Myōkō in the early eighteenth century (Kiyosawa, 'Hōzōin wo tazunereta hitobito', 101-03). Ambros (Emplacing a Pilgrimage, 123-28) has written on the case of Ōyama.
} 
elsewhere, yamabushi coordinated with the temple clerics in guiding male laity up the mountains.

It is clear from the regulations that maximizing revenue was a priority from the start. For one, the annual climbing season was limited to the dates of $6 / 15$ to $7 / 20$ in the lunar calendar. Setting this time frame not only aligned with optimal weather conditions, but the short window presumably built anticipation each spring as the opening date drew near. Secondly, various fees were built into the new policy. The temples, for instance, exacted fees from participants in exchange for talismans at passage points (sekisho 関所) stationed along the approach to the route. Regulations also stipulated services for luggage: belongings had to be placed in proper storage during the climb or transported back to the temple of Zenkojji by horseback. Rates were fixed for each item when the mountains first opened (though they most likely changed with subsequent periods of inflation). ${ }^{28}$

Climbing the two mountains appealed to a range of religious interests. First and foremost, the two-realm mandalas represented a buddha realm which had been the terrain of initiated ascetics. Applying the esoteric ritual logic of 'attainment of buddhahood in one's own body' (sokushin jöbutsu 郎身成佛) to the mountains, they undertook austerities that ontologically aligned them with the buddhas and bodhisattvas along the route. Now this realm (albeit without the same ritual program) was open to ordinary people, uninitiated into the specialized and esoteric rituals of worship in the mountains (the domain of Shugendō). Widely available gazetteers like the mid-nineteenth-century Zenkojido meisho zue highlighted details about the climb. Stressing the shift from the mundane world into the divine realm of the mandalas, the gazetteer notes that pilgrims changed into waraji 草鞋 (woven straw sandals) at the entrance of the climb. In between the summits of Takatsuma and Ototsuma they prayed at a stone where the cosmic buddha Dainichi 大日 (Mahāvairocana), central to the Diamond mandala, resided. This was followed with a prayer ritual at the 'round mirror [and the] mandala stone' (enkyō mandara ishi 圓鏡曼陀羅石) atop Otot-

28 Ryōkaizan sankei okite jōjō. 
suma. ${ }^{29}$ Such practices demonstrate a shift away from earlier ascetic rituals to lay forms of piety, albeit continued through the esoteric references of the two-realm mandalas.

In addition to the projection of a mandalic landscape were subtle hints that the two mountains brought the climber closer to the pure land. This journey began as soon as one entered the Togakushi region, as evinced by forty-eight stone distance markers set in place between Hōkoin and Okunoin shortly after the mountain opening. The correspondence of this number with Amida's 阿弥陀 (Amitâbha) vows would not have been lost to visiting pilgrims, making their approach particularly auspicious. Amida was likewise associated with Takatsuma, evident by extant illustrations from the latter half of the Edo period that depict the buddha's welcoming descent (raigo 來迎) to its summit (e.g., Figure 1). Attended by bodhisattvas Kannon 漢音 (Avalokitêśvara) and Seishi 勢至 (Mahāsthāmaprāpta), Amida’s descent suggested that one could encounter the triad there and prepare for eventual deliverance to Amida's western pure land (Sukhāvatī). Incidentally, appearance of the triad at Togakushi conjures up their famous representation at nearby Zenkōji. Indeed, most pilgrims first visited Zenkōji in the plains below before hiking up to Togakushi, apparent in numerous travelogues $(d \bar{c} c h \bar{u} k i) \cdot{ }^{30}$ Now after praying at Zenkōji, they could reaffirm their connection to Amida atop Togakushi's mandalic peaks.

While practices associated with the pure land addressed soteriological concerns among visitors, climbing the two-realm mountains also offered benefits for this lifetime. The Zenkojido meisho zue describes, to that effect, an unusual type of pine tree with branches resembling tall, slender vines located near the base of Takatsuma. According to the gazetteer, the tree's short needles ensured easy childbirth and relieved toothaches. ${ }^{31}$ The reference to childbirth here is intriguing given its relevance to women, who were not allowed access to the mountain. It could either suggest that men sought out the

\footnotetext{
29 Zenkōjidō meisho zue, 252.

30 Iwahana, 'Kinsei no tabi nikki'.

31 Zenkōiidō meisho zue, 252.
} 
pine needles for their female family members or that some women climbed this far despite the ban. In any case, reference to the needles added to the layers of efficacy available to those who ventured to these mountains.

\section{Purity versus the Purse}

Climbing Togakushi's interior mountains drew regional confraternities and independent pilgrims of the male gender, which supported the finances of the temples and yamabushi. Nonetheless, willingness to offer new forms of devotion and practice was tempered by another set of concerns: purity and pollution at the site. Rising above the mundane, quotidian world below, numinous mountains in Japan had long been viewed as purified realms. ${ }^{32}$ As Carmen Blacker discusses in her landmark study on popular Japanese religions, to defile the abode of the deities risked inciting their wrath. ${ }^{33}$ For the mountain gods, this rage translated into the potential for bad weather, plagues, and poor harvests for the communities living below.

That the Togakushi clerics and other mountain communities expanded access to their peaks, despite these fears, suggests an underlying economic incentive in play. However, this tradeoff appears to have not sat well for some residents living under the mountain. For villagers not associated with the temples, particularly farmers cultivating rice, soba, and other produce, the possibility that any average Jirō could now trudge up the mandalic peaks, hauling his impurities in tote, provoked the threat of crop and property damage. Such unrest is palpable in a diary of the acting administrator (daikan

32 Early examples appear in the Nibon ryoiki 日本霊異記 (ca. 824) and the tenth-century Engishiki 延喜式. For secondary scholarship on issues of purity and Japanese mountains, see for example, Grapard ('Geotyping Sacred Space', 230-33) and Satō ('Changes in the Concepts of Mountains in Japan', 90-97).

33 Blacker, The Catalpa Bow, 41. See also Schnell ('Are Mountain Gods Vindictive?') on divergent views regarding alpine access between two types of mountain communities (hunting versus agricultural) in nineteenth-century Japan. 
代官), Okawa Rokubē 小川六兵衛 around the time of the opening. An entry on $6 / 13$ of 1701 , for instance, notes that villagers blamed the impending mountain opening (just two days away) on a recent flood in Kyoto. Another entry from 7/22 contains accusations from villagers that the mountain opening was causing high winds that had damaged their crops. ${ }^{34}$ These rumors reflect the power-both efficacious and menacing - that villagers living outside of the temple vicinity attributed to the Togakushi mountains and their divine inhabitants.

Anticipating such concerns, chief administrator Ken'yū had added protocol intended to reduce the risk of pollution. For instance, the night before the climb, participants were required to ritually purify themselves by taking a hot-water bath (yudono gyo 湯殿行). This step not only cleansed them for their communion with the mountains' buddhas and bodhisattvas but also mitigated the risk of defiling the alpine realm. Similar rituals of purification were also enacted at the mountain temples of Yudono 湯殿 and Ōyama after they opened their own peaks to lay entrance. ${ }^{35}$

With these cautionary steps in place, laity could now be guided into the numinous landscape, save but for one significant sector of the population: women. As was the case with numerous religious mountains in premodern Japan, a prohibitory boundary for women was enforced at Togakushi by the temples at certain points in history. The language used for women's exclusion from religious sites in Japan was either nyonin kinsei 女人禁制 (prohibition of women) or nyonin kekkai 女人結界 (women's boundaries). Beginning in the early eighth century, legal stipulations in the Yörō Code, based on Vinaya codes related to sexual misconduct, restricted women from visiting monks' quarters and vice versa, except in special circumstances (illness, instruction, etc.). ${ }^{36}$ The earliest-known Buddhist mountain in Japan

\footnotetext{
34 Okawa binamiki.

35 Wakamori, 'Togakushi no Shugendō', 421; Ambros, Emplacing a Pilgrimage, 124-25.

36 These rules are found in the 'Regulations for Monks and Nuns' (Sōni ryō) section of the Yörō Code, articles 11 and 12. Ushiyama Yoshiyuki ('Historical De-
} 
known to exclude women was Hiei, center of the Tendai lineages. Restrictions at Hiei date back to 818, when Saichō instituted measures aimed at preventing women, alcohol, and theft at the mountain, rules ostensibly enacted for the purpose of training novices. ${ }^{37}$

While early restrictions against women may have been based on monastic precepts, the logic transformed in the centuries that followed, as an entire discourse emerged that explained the female body as a source of impurity. ${ }^{38}$ It drew from a disparate patchwork of continental notions of yin and yang, the Confucian ideal of a woman's 'three duties' (to serve her father, husband, and then son; sanshō 三従), and the 'five obstacles' (goshō 五障) preventing the attainment of buddhahood, a notion raised in the Lotus Sütra account of the Dragon Girl (which uses the list as a foil to be disproved by the girl's transformation into a bodhisattva). At powerful mountain centers (e.g., Hiei, Kōya, and Kinpusen) connected to elite patrons in the capital, legends surfaced depicting lofty female practitioners incurring the wrath of the mountain gods after soiling the slopes with a drop of menstrual blood or urine. As divine punishment, they were transformed into landmarks on the trails-footprints, trees, boulders - to be invoked as warnings to later generations of devout women. These legends were retold at other mountains over time, peaking in the Edo period. Even more pervasive throughout society was the Blood Pool Sūtra (Ketsubon kyō 血盆經), a Chinese apocryphal text describing a special hell reserved for women as karmic retribution for their impure nature. This doctrine captured the popular imagination in Chinese society, as evident in popular

velopment of the Exclusion') expands from this evidence to argue that the prohibitions (kinsei) were based in gender-neutral policies. Others have countered that discourse on pollution played a larger role: see Katsuura, Kodai / chüsei no josei to bukkyo; and Faure, The Power of Denial, 220-21.

37 Groner, Ryōgen and Mount Hiei, 436; Ushiyama, 'Historical Development of the Exclusion', 42-43.

38 Much has been written on this topic in the past several decades. Overviews include Suzuki, Nyonin kinsei; Ushiyama, “Nyonin kinsei” sairon'; and Moerman, Localizing Paradise, chapter 5. 
sagas retold through the Qing Dynasty. ${ }^{39}$ Wakita Haruko argues that upon its transmission to Japan (ca. fifteenth century), awareness of the sütra emerged within elite society but permeated society by the Edo period. ${ }^{40}$

Previous scholarship on the topic of exclusionary zones has often framed the practice as widespread across the country's mountains during the premodern period. The lack of medieval extant sources from most mountain centers encourages such generalizations, but the evidence is often limited to scattered legendary accounts. Yet as Miyazaki Fumiko has argued through evidence from contemporaneous travel diaries, restrictions against women's entrance to religious mountains increased dramatically in the latter half of the Edo period. ${ }^{41}$ This evidence is bolstered when we consider the histories of specific sites. Taking the case of Togakushi, some form of boundary excluding women at Togakushi first appears in the mid-fifteenth century but was a point of contention among the mountain's clerics, as evident in contemporaneous legends both justifying and admonishing the practice. ${ }^{42}$ This controversy and lack of personal accounts makes it difficult to assess the extent to which an exclusionary policy was enforced at the time.

In contrast, vigilance over the ban seems to have escalated in the early eighteenth century. In 1705, just four years following the mountain opening, a pillar announcing the boundary was erected on the road between Chūin and Okunoin. A second pillar was later erected in 1795 , reinforcing the existing signage. ${ }^{43}$ The pillars desig-

39 See an introduction and translation of two tales in Grant and Idema, Escape from Blood Pond Hell.

40 Wakita, 'Nyonin kinsei to shokue shisō'. For discussion and translation of one transmission of the text, see Takemi " Menstruation Sutra” Belief in Japan'. Hirasawa (Hell-bent for Heaven) examines how the cosmology of the Blood Bowl Hell was imagined onto the landscape of Mount Tateyama 立山 (Toyama prefecture).

\footnotetext{
41 Miyazaki, 'Nyonin kinsei', 53.

42 Togakushisan Kenkōi ruki, 378, 384.

43 Horii and Imai, Kodō wo aruku, 86-87.
} 
nated an exclusionary zone that encompassed the Okunoin temple, its twelve cloisters, the shrine of Kuzuryū, and the two-realm mountains. ${ }^{44}$ Around this time is also the first recorded appearance of local legend about a nun punished for crossing into the exclusion zone. In his visit to the mountain in 1784, travel writer Sugae Masumi (1754-1829) mentions in passing a bikuni ishi 比丘尼石, or 'nun's stone' just beyond the boundary. ${ }^{45}$ The boulder presented an alleged physical trace of transgression by an eminent nun who turned to stone after crossing the boundary line. The brevity of the reference and the fact that Sugae felt it required no further explanation shows how common the legend had become by this time.

The timing of this escalation, beginning at the start of the eighteenth century, raises the question: why was the risk of pollution by increased male traffic up the slopes of Takatsuma and Ototsuma tolerated by the temples while restrictions against women were intensifying? To understand this seeming contradiction, we might look at two sets of concerns: economic interests, on the one hand, and anxieties over pollution, on the other. Economic motivations present a few possible rationales. First of all, maybe the financial risks of excluding women were viewed as minimal. Their prohibition from one part of the site (albeit the most sacred) apparently did not stop all women from visiting Togakushi. A women's hall was erected at the boundary (Figure 3; also refer to Figure 1). As Sugae wrote in his travel account, near the nun's stone:

there is a women's hall for the bodhisattva Kannon. Women ascending from the foot of the mountain on pilgrimage (mōde 詣で) are permitted to come this far. Therefore, they all return home [from here]. ${ }^{46}$

The very existence of the hall reveals that women continued to visit the site in significant numbers, despite their exclusion beyond

\footnotetext{
44 Ushiyama, 'Togakushi ni dai', 84.

45 Sugae, Sugae Masumi yüranki, 67.

46 Sugae, 67.
} 




FIG. 3 Commemorative markers of the women's hall and boundary excluding women. The boundary was situated at this fork: left immediately entering the exclusionary zone; right leading to the neighboring province of Echigo (both are directed by the stele; right, ca. 1808).

the boundary. As a result, the clerics may have felt that women would visit Togakushi even if certain parts were off-limits. At the same time, they must have been aware that some financial gains would be lost by excluding women. Fees for mountain climbing (tolls, luggage storage, etc.), after all, could only be extracted from male visitors.

As a second possibility, perhaps the basic act of exclusion was intended to add value for male patronage. In other words, restricting access to the two-realm mountains may have made the climb all the more enticing for men. The logic of limiting access for increased demand, in fact was already in play with the restricted climbing season of one month out of the year. Yet there are problems with this point of speculation. Mention of the ban, for instance, does not appear in the site's promotional and lay-oriented literature (engi 縁起 [origin accounts], reigenki 霊験記 [miracle tales], etc.), indicating that the clerics or yamabushi were not seeking to highlight the boundary as a selling point for men. Furthermore, some mountain temples around the country appear to have viewed the 
exclusionary practices at Togakushi and elsewhere as an opportunity for themselves. Sherry Fowler's study on Mount Murō 室生 (near Nara), for example, shows that by the late seventeenth century, the Shingon temple of Murōji welcomed women. As a result, the mountain became popularly known as 'Nyonin Kōya' (Women's Mount Kōya) as a point of direct contrast with Mount Kōya 高野山 (also Shingon; founded by Kūkai 空海), long known for its exclusion of women. ${ }^{47}$

Debates over women's exclusion at Mount Fuji in the late Edo period are particularly helpful in offering comparative evidence for Togakushi. Miyazaki Fumiko's research reveals that while the highest (and most iconic) mountain of Japan was off limits to women for most of the Edo period, pilgrimage guides (oshi 御師) working the Yoshida 吉田 route (northeast face) began chipping away at these restrictions in the nineteenth century. Motivations behind this process varied. For Fuji confraternities (Fujikō 富士講) who traced their lineages to the ascetic Jikigyō Miroku 食行身禄 (1671-1733), the moral dimension of the policy served as the driving imperative in undoing the ban. Jikigyō had attacked the notion of the 'five obstructions', arguing that men and women should be viewed on equal terms. Among his final teachings, delivered over thirty-three days of ascesis on the mountain (and later compiled by his disciples), he pronounced that 'sex plays no role in determining one's nature as good or evil'. ${ }^{48}$ This statement directly challenged the prevailing notion that women were defiled and karmically hindered by nature. His teachings were further developed in the confraternity of Fujidō 不二道, a double entendre indicating that the 'way of Fuji' was a 'way of nonduality' between yin and yang, and by extension, between genders. ${ }^{49}$ For members of this association, unrestricted access up Fuji for women was not simply a matter of equality but of doctrinal urgency.

47 Fowler, Murōii, 66-74. For exclusionary policies at Kōya, see Matisoff, 'Barred from Paradise'.

48 Sanjūichinichi no otsutae, 542.

49 Miyazaki, 'Female Pilgrims and Mt. Fuji', 349-51, and 'Nyonin kinsei'. 
For those who relied on income from pilgrims, furthermore, economics represented an additional concern. Facing declining revenues amid competition from guides on other routes up Fuji, the guides of the Yoshida route began actively encouraging female devotees of the mountain to join them. Between 1800 and 1872 (when the government ordered an end to the practice nationwide), the guides successfully petitioned local authorities (who controlled access) to allow women to reach increasingly higher points on the route on certain auspicious years. Due to these efforts, more women and men enlisted their services, leading guides on other routes to adopt similarly inclusive policies toward women. ${ }^{50}$

One final group, however, opposed loosening the boundaries against women. Vulnerable to natural disasters on the mountain (eruptions, avalanches, etc.) and concerned about rice crops (as either farmers or consumers), villagers living at the base of Fuji feared that women's presence on the mountain would provoke the wrath of its deities, potentially resulting in disasters, flooding, and famine. As such, they issued complaints to the local government authorities. Their calls for strict enforcement of the ban made a simple end to it difficult, requiring decades of incremental progress on the part of the guides and confraternities. ${ }^{51}$

This evidence demonstrates that villagers viewed the prospect of women on Mount Fuji as a direct threat to their lives and livelihoods. Their active opposition presented the greatest impediment to more inclusive (and profitable) pilgrimage protocol. Similarly with Togakushi, increased access to the mountain terrain prompted serious concerns among villagers. Yet in contrast to the situation at Fuji (and at least a century before), the Tendai Buddhist administration appears to have made a calculated trade off: allow laymen on the numinous mountain while ramping up the exclusion of women from other areas. Furthermore, while guides at Fuji actively pushed for women's inclusion, Togakushi's yamabushi appear to have been complicit in the restrictions.

\footnotetext{
50 Miyazaki, 'Female Pilgrims and Mt. Fuji', 353-72.

51 Miyazaki, 356-61.
} 
The bustling scene of passersby on their way to and from Mount Togakushi at the opening of this article recalls Togakushi's popularity in the eighteenth century, despite the mountain's remote distance from the country's urban centers. This success was fostered by decisions made by the clerics and yamabushi to import new Shinto deities, Shugendo culture, and as discussed in this article, the development of confraternities and mountain climbing. These activities raised additional revenue beyond the fixed tax income (from agricultural fields) allotted by the military government, making them central to economic expansion for the temples.

When this growth is examined alongside increasing exclusionary policies against women in the Edo period, two observations can be made. First, the historical practice of women's exclusion was not applied in a sweeping fashion across Japan's premodern Buddhist mountains at large, as sometimes suggested in previous scholarship but rather, varied according to time, place, and the extent of enforcement. While limited in scope, the evidence above suggests that these discriminatory policies (or conversely, their contestation) coincided especially at times of growth for mountain temples and shrines, most notably the wave of pilgrimage and travel that took off in the eighteenth century.

Second, matters regarding pilgrimage and women's exclusion often developed within arenas of competing interests. With the influx of travel to numinous mountains in the eighteenth century, so came the fear of spiritual defilement. Pervasive notions about the female body as a source of pollution thrust local communities into intense negotiations that revolved around faith, money, and social fears. These issues varied according to the interests of the affected stakeholders. Records from sites like Fuji and Murōji attest that many women did want to climb numinous mountains on equal terms with men. Even if Buddhist mountain temples and the affiliated mountain guides saw economic potential (and sometimes ethical reasoning) in their inclusion, they could face dissent from villagers who perceived that very access as an existential threat.

It would be misleading to suggest that mountain villagers played 
a greater role than Buddhist temples in the advancement of women's exclusion from numinous mountains in early modern Japan. Indeed, it was the temples that enforced the boundaries within their own territories (shinryō 神領). Nevertheless, cases like that of Togakushi and Fuji reveal that complex, often competing interests often arose in the development of pilgrimage and exclusion of women at Buddhist mountains in early modern Japan.

\section{Bibliography}

\section{Primary Sources}

Okawa binamiki 小川日次記 [Diary of the Okawa]. By Okawa Rokubē 小川六兵衛 (active in the 17th c.), ca. 1700-1702. Transcribed by Futazawa Hisaaki 二澤久昭. Unpublished. Ryōkaizan sankei okite jojō 両界山参詣掟条々 [Regulations for pilgrimage into the two-realm mandalas]. By Ken'yū 見雄 (d. 1702), 1701. Printed in Nagano kenshi 長野県史 [History of Nagano Prefecture], vol. 3, no. 2113: 791. Nagano City: Nagano Kenshi Kankōkai 長野県史刊行会, 1982.

Sanjüichinichi no otsutae 三十一日乃御伝 [The Teachings of thirtyone days]. Compiled by disciples of Jikigyō Miroku 食行身 禄 (1671-1733), ca. 1733. In Fujikō no rekishi: Edo shomin no sangaku shinkō 富士講の歴史 : 江戸庶民の山岳信仰 [The History of Fuji confraternities: Mountain worship of Edo commoners], edited by Iwashina Koichirō 岩科小一郎, 535-51. Tokyo: Meicho Shuppan 名著出版, 2000.

Shinshū Togakushisan sōryaku ezu 信州戸隠山惣略繪圖 [Illustrated general map of Mount Togakushi in Shinshū]. Illustrator unknown, ca. late Edo period. Author's collection.

Sugae Masumi yüranki 菅江真澄遊覧記 [Sugae Masumi's sightseeing chronicles]. By Sugae Masumi (1754-1829), ca. 1784. Uchida Takeshi 内田武志 and Miyamoto Tsuneichi 宮本常一, eds.

Tokyo: Heibonsha 平凡社, 1965.

Togakushisan Kenkōji ruki (narabi ni jo) 戸隠山顯光寺流記 (並

序) [Transmitted account of the temples of Kenkōji of Mount 
Togakushi (with preface)]. Compiled by Jikkokusō Ujō 十穀僧有 通, 1458. In Shintō Taikei 神道体系 59, edited by Yoshioka Isao 吉岡勲 and Nishigaki Seiji 西垣晴次, 376-85. Jinja hen 神社編 24. Tokyo: Shinto Taikei Hensankai 神道大系編纂会, 1983.

Zenkojjidó meisho zue 善光寺道名所圖會 [Gazetteer for famous sites along the Zenkōji road]. 5 fasc. By Toyoda Toshitada 豊田利 忠, 1843. Edited by the Shinano Shiryō Kankōkai 信濃資料刊行 会, vol. 21. Nagano: Shinano Shiryō Kankōkai 信濃資料刊行会, 1979.

\section{Secondary Studies}

Ambros, Barbara. Emplacing a Pilgrimage, The Oyama Cult and Regional Religion in Early Modern Japan. Cambridge: Harvard University Press, 2008.

- - . 'Geography, Environment, and Pilgrimage'. In Nanzan Guide to Japanese Religions, edited by Paul Swanson and Clark Chilson, 289-308. Honolulu: University of Hawai'i Press, 2006. Badone, Ellen. 'Crossing Boundaries: Exploring the Borderlands of Ethnography, Tourism, and Pilgrimage'. In Intersecting Journeys: The Anthropology of Pilgrimage and Tourism, edited by Ellen Badone and Sharon R. Roseman, 180-89. Chicago: University of Illinois Press, 2004.

Blacker, Carmen. The Catalpa Bow: A Study of Shamanic Practices in Japan. London: George Allen and Unwin, 1975.

DeWitt, Lindsey E. 'Envisioning and Observing Women's Exclusion from Sacred Mountains in Japan'. Journal of Asian Humanities at Kyusbu University 1 (2016): 19-28.

- - - 'A Mountain Set Apart: Female Exclusion, Buddhism, and Tradition at Modern Ōminesan, Japan'. Ph.D. dissertation.

University of California, Los Angeles, 2015.

Drixler, Fabian. Mabiki: Infanticide and Population Growth in Eastern Japan, 1660-1950. Berkeley: University of California Press, 2013.

Faure, Bernard. The Power of Denial: Buddhism, Purity, and Gender. Princeton: Princeton University Press, 2003.

Fowler, Sherry D. Murōji: Rearranging Art and History at a Japanese 
Buddhist Temple. Honolulu: University of Hawai'i Press, 2005. Furukawa Sadao 古川貞雄. 'Togakushisan shinryō no seiritsu to tenkai' 戸隠山神領の成立と展開 [The establishment and development of Mount Togakushi's divine region]. In Togakushi shinkō no rekishi 戸隠信仰の歴史 [The history of worship at Togakushi], edited by Futazawa Hisaaki 二澤久昭, Hisayama Katsuhiko 久山勝彦, Kyōgoku Okikazu 京極興一, and Oshi Norito 越志徳門, 61-98. Togakushi Mura: Togakushi Jinja 戸隠 神社, 1997.

Grant, Beata, and W. L. Idema. Escape from Blood Pond Hell: The Tales of Mulian and Woman Huang. Seattle: University of Washington Press, 2014.

Grapard, Allan. 'Geotyping Sacred Space: The Case of Mount Hiko in Japan'. In Sacred Space: Shrine, City, Land, edited by Joshua Prawer, B. Z. Kedar, and R. J. Zwi Werblowsky, 215-49. New York: New York University Press, 1998.

Groner, Paul. Ryogen and Mount Hiei:Japanese Tendai in the Tenth Century. Honolulu: University of Hawai' i Press, 2002.

Hirasawa, Caroline. Hell-bent for Heaven in Tateyama Mandara: Painting and Religious Practice at a Japanese Mountain. Leiden: Brill, 2013.

Hōgetsu Keigo 宝月圭吾. ‘Edo jidai ni okeru Togakushi oshi’ 江戸 時代における戸隠御師 [Togakushi oshi during the Edo period]. In Fuji, Ontake to Chübu reizan 富士、御嶽と中部霊山 [Mounts Fuji, Ontake, and the sacred peaks of the central region], edited by Suzuki Shōei 鈴木昭英, 342-56. Sangaku shūkyōshi kenkyū sōsho 山岳宗教史研究叢書 [Series of Studies on the History of Mountain Religion], vol. 9. Tokyo: Meicho Shuppan 名著出版, 1978.

Horii Ken'ichi 堀井謙一, and Imai Satoshi 今井達. Kodō wo aruku: Togakushi Jinja gosha meguri 古道を歩く: 戸隠神社五社めぐり [Walking on the ancient roads: Taking tour of the five shrines of Togakushi Jinja]. Nagano City: Shinano Mainichi Shinbun 信濃 毎日新聞, 2013.

Hur, Nam-lin. Prayer and Play in Late Tokugawa Japan: Asakusa Sensōji and Edo Society. Cambridge: Harvard University Asia Center, 2000. 
Iwahana Michiaki 岩鼻通明. 'Kinsei no tabi nikki ni miru Zenkōji/ Togakushi sankei’ 近世の旅日記にみる善光寺・戸隠参詣 [Zenkōji and Togakushi pilgrimage in early modern travelogues]. Nagano 長野 165 (1992): 16-38.

. 'Togakushi shinkō no chiikiteki tenkai' 戸隠信仰の地域的展 開 [The Regional development of Togakushi worship]. Sangaku Shugen 山岳修驗 [Japanese Mountain Religion] 10 (1992): 31-40.

. Kodai/cbusei no josei to bukkyo 古代•中世の女性と仏 教 [Ancient and medieval women and Buddhism]. Tokyo: Yamakawa Shuppansha 山川出版社, 2003.

Katsuura Noriko 勝浦令子. 'Josei to kegarekan’女性と穢れ観 [Women and views on defilement]. Bukkyō shigaku kenkyū 佛教 史学研究 [Studies in Buddhist History] 51, no. 2 (2009): 1-20.

Kiyosawa Satoshi 清沢聰. ‘Hōzōin wo tazunereta hitobito'宝蔵院を 訪ねれた人々 [Visitors of Hōzōin]. In Hōzōin nikki no fūkei 宝蔵 院日記の風景 [Viewing the diaries of Hōzōin], edited by Myōkō Shi Kyōikuiinkai 妙高市教育委員会, 100-40. Myōkō: Myōkō Shi Kyōikuiinkai 妙高市教育委員会, 2010.

Kobayashi Keiichirō 小林計一郎. Zenkōji shi kenkyū 善光寺史研究 [Research on the history of Zenkōji]. Nagano: Shinano Mainichi Shinbunsha 信濃每日新聞社, 2005.

Matisoff, Susan. 'Barred from History? Mount Kōya and the Karukaya Legend'. In Engendering Faith: Women and Buddhism in Premodern Japan, edited by Barbara Ruch, 463-500. Ann Arbor: University of Michigan, 2002.

Miyake Hitoshi 宮家準. 'Shugendō’. In A History of Japanese Religion, edited by Kazuo Kasahara, translated by Paul McCarthy and Gaynor Sekimori, 455-74. Tokyo: Kosei Publishing Co., 2001.

Miyazaki Fumiko 宮崎ふみ子. 'Female Pilgrims and Mt. Fuji: Changing Perspectives on the Exclusion of Women.' Monumenta Nipponica 60, no. 3 (2005): 339-91.

- ——. 'Nyonin kinsei: Fuji tohai o megutte' 女人禁制:富士登捧 をめぐって [Prohibitions against women: Mountain-climbing worship on Fuji]. In Tasha to kyōkai 他者と境界 [Others and objects], edited by Shimazono Susumu 島薗進 et al., 51-86. 
Tokyo: Shunjūsha 春秋社, 2015.

Miyata Noboru 宮田登. 'Togakushi shinkō to Mimachi' 戸隠信仰と 已待ち [Togakushi worship and the Mimachi cult]. In Sangaku shükyō to minkan shinkō no kenkyū 山岳宗敎と民間信仰の研究 [Research on mountain religion and popular worship], edited by Sakurai Tokutarō 桜井徳太郎, 436-55. Sangaku shūkyōshi kenkyū sōsho 山岳宗教史研究叢書 [Series of Studies on the History of Mountain Religion], vol. 6. Tokyo: Meicho Shuppan 名著出版, 1976.

Moerman, Max. Localizing Paradise: Kumano Pilgrimage and the Religious Landscape of Premodern Japan. Cambridge: Harvard University Press, 2005.

Naquin, Susan, and Yü Chün-fang, eds. Pilgrims and Sacred Sites in China. Berkeley: University of California Press, 1992.

Nenzi, Laura. The Chaos and Cosmos of Kurosawa Tokiko: One Woman's Transit from Tokugawa to Meiji Japan. Honolulu: University of Hawai'i Press, 2015.

- - Excursions in Identity: Travel and the Intersection of Place, Gender, and Status in Edo Japan. Honolulu: University of Hawai'i Press, 2008.

Pye, Michael. Japanese Buddhist Pilgrimage. Bristol: Equinox, 2015. Reader, Ian. Making Pilgrimages: Meaning and Practice in Shikoku. Honolulu: University of Hawai'i Press, 2005.

Robson, James. Power of Place: The Religious Landscape of the

Southern Sacred Peak (Nanyue) in Medieval China. Cambridge: Harvard University Asia Center, 2009.

Satō Hiroo 佐藤弘夫. 'Changes in the Concepts of Mountains in

Japan'. Cahiers d'Extrême-Asie [East Asian Journal] 18 (2009):

89-102.

Schnell, Scott. 'Are Mountain Gods Vindictive? Competing Images of the Japanese Alpine Landscape'. Journal of the Royal Anthropological Institute 13 (2007): 863-80.

Schopen, Gregory. 'Archeology and Protestant Presuppositions'.

History of Religions 31, no. 1 (1991), 1-23.

Sekimori, Gaynor. 'Paper Fowl and Wooden Fish: The Separation of Kami and Buddha Worship in Haguro Shugendō, 1869-1875'. Japanese Journal of Religious Studies 32, no. 2 (2005): 197-234. 
Shinjō Tsunezō 新城常三. Shinkō shaji sankei no shakai keizaishiteki kenkyu u 新稿社寺参詣の社会経済史的研究 [Social and economic historical research on pilgrimage to shrines and temples (New edition)]. Tokyo: Hanawa Shobō 塙書房, 1982 (1964).

Shinno Toshikazu 真野俊和. 'Journeys, Pilgrimages, Excursions: Religious Travels in the Early Modern Period' (originally 'Tabi, junrei, yusan: Kinsei sankei jijō’ 旅、巡礼、遊山一一近世参詣事情, 1993). Translated by Laura Nenzi. Monumenta Nipponica 57, no. 4 (2002): 447-71.

Suzuki Masataka 鈴木正崇. Nyonin kinsei 女人禁制 [Prohibitions against women]. Tokyo: Yoshikawa Kōbunkan 吉川弘文館, 2002.

Takemi Momoko. “"Menstruation Sutra” Belief in Japan'. Japanese Journal of Religious Studies 10, nos. 2-3 (1983): 229-46.

Tamamuro Fumio 圭室文雄. Nibon bukkyō shi: kinsei 日本仏教史: 近世 [History of Japanese Buddhism: Early modern]. Tokyo: Yoshikawa Kōbunkan 吉川弘文館, 1987.

Ten Grotenhuis, Elizabeth. Japanese Mandalas: Representations of Sacred Geography. Honolulu: University of Hawai'i Press, 1999.

Thal, Sarah. Rearranging the Landscape of the Gods: The Politics of a Pilgrimage Site in Japan, 1573-1912. Chicago: University of Chicago Press, 2005.

Tsuji Zennosuke 辻善之助. Nihon bukkyōshi: Dai hachikan kinsei ben no ni 日本仏教史: 第8卷, 近世篇之二 [The History of Japanese Buddhism: No. 8, early modern, vol. 2]. Tokyo: Iwanami Shoten 岩波書店, 1992 (1953).

Ushiyama Yoshiyuki 牛山佳幸. 'The Historical Development of the Exclusion of Women from Sacred Places (prohibitions against women) in Japan'. Acta Asiatica 97 (2009), 39-55.

- - _. “'Nyonin kinsei” sairon’「女人禁制」再論 [A

Reconsideration of nyonin kinsei]. Sangaku Shugen 山岳修験 [Japanese Mountain Religion] 17 (1996): 1-11.

_-_. 'Togakushi ni dai: "Nyonin kinsei” to Hakutaku shinkō to' 戸隠二題:「女人禁制」と白沢信仰と [Two subjects on Togakushi: The 'Prohibition of women' and Hakutaku worship]. In Nagano Shiritsu Hakubutsukan dai sanjügo kai tokubetsu ten, 'Shinano

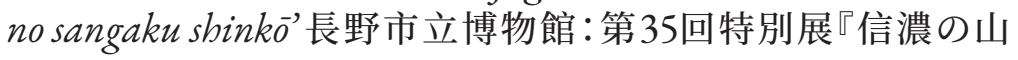


岳信仰』[Nagano City Museum: Number 35 special exhibition, 'Mountain worship in Shinano'], 84-93. Nagano Shi: Nagano Shiritsu Hakubutsukan 長野市立博物館, 1994.

Wakamori Tarō 和歌森太郎. ‘Togakushi no Shugendō’ 戸隠の修験 道 [Togakushi Shugendō]. In Wakamori Tarō chosakushū 和歌 森太郎著作集 [Collected Works of Wakamori Tarō] 2, 394-431. Tokyo: Kōbundō 弘文堂, 1980 (1971).

Wakita Haruko 脇田晴子. 'Nyonin kinsei to shokue shisō’ 女人禁 制と触穢思想 [Prohibitions against women and the concept of defilement]. Nyonin shigaku 女性史学 [Historical Studies of Women] 15 (2004): 1-14.

Yü, Chün-Fang. Kuan-yin: The Chinese Transformation of Avalokitếviva. New York: Columbia University Press, 2001. 